ORIGINAL ARTICLE

\title{
The Correlation Between Marital Age and The Incidence of Cervical Cancer
}

\author{
DWI MARGARETA ANDINI ${ }^{1}$, DESSY LUTFIASARI ${ }^{2}$ \\ ${ }^{1}$ Faculty of Health Science, Kediri University of Kediri \\ ${ }^{2}$ Faculty of Health Science, 'Aisyiyah University of Yogyakarta \\ Correspondent author to Dwi Margareta Andini email :dini_margaretha@yahoo.co.id
}

\begin{abstract}
Background: Cervical cancer (neck of the womb) is a malignant tumor that grows in the cervix (the lowest part of the uterus attached to the top of the vagina).

Aim: This study aims to investigate the correlation between marital age and the incidence of cervical cancer. Methods: This research was correlation analytic with a cross-sectional approach. This study's population was all patients in Gambiran Hospital in obstetric and gynecology poly, and the sample size was 34 people chosen by simple random sampling technique. The research instrument used the medical record. The bivariate analysis used the Spearman rank test.

Results: The analysis shows that there were two independent and dependent variables, namely marital age and the incidence of cervical cancer, with $\rho$ value $=0001<\alpha=0.05$ indicating that there was a correlation between marital age and the incidence of cervical cancer with a value of $r=0.549$ showed that there is a relationship between the age of marriage with cervical cancer incidence.

Conclusion: This research is expected to be an input to make people more healthy and open to receive health information, especially if a family has a child of early marriage age.

Keywords: Cervical Cancer, Marital Age.
\end{abstract}

\section{INTRODUCTION}

Cervical cancer occurs in the uterine cervix, and a female reproductive organ functioned as the entrance to the uterus located between the womb (uterus) and the vagina [1]. Early-stage cervical cancer does not cause any disturbance and often does not lead to a real change from the cervix. Nevertheless, it should be considered if any of the following symptoms happen: early stage: The early stages of cervical cancer have not shown any symptoms or tend not detected, stage I: In stage I, there are no perceived grievances, one significant sign is bleeding during intercourse, stage II: In Stage II, the symptoms tend to arise such as abnormal, smelly, exaggerated, and can not be healed vaginal discharge, spontaneous bleeding, pain or discomfort during intercourse. Stage III: pain in the pelvic cavity due to dam cancer, pain during urination, swelling in the legs because of the emphasis on veins and pressure on the respiratory, pain in the lower back. Stage IV: hemoptysis, jaundice, urinary, and dysentery. Factors Affecting the Incidence of Cervical Cancer: Age, age of first marriage, Parity, Education, Employment, Employment mother or a mother of activities. Cervical cancer symptoms are divided into several phases: The period without symptoms, vaginal discharge, bleeding, pain. When doctors suspect a disorder associated with cervical cancer, they will conduct several actions: Pap smear, Biopsy, colposcopy, Konisasi, IVA (Visual Inspection Acetate), Visual Inspection using acetic acid.

According to the Marriage Act No. 27, In 2012, the ideal marital age is more than 20 years for women and over 25 years for men. In general, a physically ready woman is a woman who has completed her growth at around the age of 20 years. However, women who have not reached the age of 20 years are already in physical development. The body has not developed its full potential, and it is necessary to consider the obstacles or disadvantages. For example, marriage at a young age (under 20 years) is often associated with abnormal cells on the cervix. It is closely related to the incomplete development of reproductive organs [2]. Sexually active young women have a greater risk of developing cervical cancer. It is due to the immature cervical cells. The cells will mature when it gets older and can withstand the process generated due to sexual penetration. This process can damage cells mature before this tender. Some studies suggest that sexual intercourse under 21 years has the most significant risk of abnormal cells' onset [3]. Cervical cancer patients are found at the age of $45-50$ years who past menopause in which the menstruation period is stopped so that the reproductive organ function at the age of 45-50 years decreases. The immediate cause of cervical cancer is not yet known. There is strong evidence of events have strong relationships with several extrinsic factors, such as what is important is seldom found in virgin, incidence high in those who married than unmarried, especially for the girl whom coitus first experienced at a very young age $<17$ years is known to stimulate the growth of cancer cells in women's gynecologic, because in the age range 12-17 years, changes in the cells are dividing actively (metaplasia), ideally no contact or stimulation from the outside, including injus (influx) of foreign objects in the body of women. The presence of a foreign body, including the genitals of men and sperm cells, will lead to abnormal cells' development in the direction. Especially if it comes to injuries that can lead to infection in the uterus, the cervix's abnormal cells can lead to cervical cancer [4].

Purpose: This study aims to investigate the correlation between marital age and the incidence of cervical cancer.

\section{METHOD}

This study's design is described as follows: based on the study's scope, the study was inferential study design techniques. Based on the research site, this study was field research. Based on the timing of data collection, this 
study employed a cross-sectional design. Based on the data collection technique, the study was survey research. Based on the presence or absence of treatment, the study was ex post facto research. Based on the research objectives, the study was correlation analytical research. Based on the data source, this study used a secondary research design.

\section{RESULT}

Table 1: Frequency distribution of respondents according to marital age.

\begin{tabular}{|l|l|l|}
\hline Marriageable & frequency & $(\%)$ \\
\hline Age & & \\
\hline$<20$ & 20 & 58,8 \\
\hline $20-35$ & 14 & 41,2 \\
\hline$>35$ & 0 & 0 \\
\hline Total & 34 & 100 \\
\hline
\end{tabular}

Table 2: Frequency of respondents according to cervical cancer incidence.

\begin{tabular}{|l|l|l|}
\hline Cervical Cancer & frequency & Percentage (\%) \\
\hline Cervix Cancer & 16 & 47,1 \\
\hline Not Cancer Cervix & 18 & 52,9 \\
\hline Total & 34 & 100 \\
\hline
\end{tabular}

Table 3: Frequency of respondent's marital age to cervical cancer incidence.

\begin{tabular}{|c|c|c|c|c|c|c|}
\hline \multirow{3}{*}{ Marital age } & \multicolumn{4}{|c|}{ Cervical Cancer } & \multirow{2}{*}{\multicolumn{2}{|c|}{ Total }} \\
\hline & \multicolumn{2}{|c|}{$\begin{array}{l}\text { Cervical } \\
\text { Cancer }\end{array}$} & \multicolumn{2}{|c|}{$\begin{array}{l}\text { Not Cervical } \\
\text { Cancer }\end{array}$} & & \\
\hline & $f$ & $\%$ & $\mathrm{~F}$ & $\%$ & $f$ & $\%$ \\
\hline$<20$ & 12 & 66.7 & 2 & 12,5 & 14 & 41,2 \\
\hline $20-35$ & 6 & 33.3 & 14 & 87.5 & 20 & 58.8 \\
\hline$>35$ & 0 & 0 & 0 & 0 & 0 & 0 \\
\hline Total & 18 & 100 & 16 & 100 & 34 & 100 \\
\hline \multicolumn{2}{|l|}{$\rho=0.001$} & \multicolumn{3}{|c|}{$r=0.549$} & \multicolumn{2}{|c|}{$\alpha=0.05$} \\
\hline
\end{tabular}

Based on the Table can be interpreted that the majority $(66.7 \%)$ of respondents who got married at the age of $<20$ years suffered from cervical cancer.

\section{DISCUSSION}

Statistical test results using the Spearman rank test showed the value of $\rho$ value $=0.001<\alpha=0.05$, which means that $\mathrm{H} 0$ was rejected and $\mathrm{H} 1$ was accepted. It can be concluded that there was a correlation between marital age and cervical cancer incidence, with a correlation coefficient of $r=0.549$ indicating a strong correlation with the direction $(+)$. It means that the lower the marital age, the lower the number of respondents who did not have cervical cancer. Most (66.7\%) of respondents in the marital age of 20-35 had cervical cancer as many as 12 people.
Marital age under 17 years is known to stimulate cancer cells' growth in women's gynecologic because, in the age of 12-17, changes in the cervical cells are active. Keep in mind, when cells are dividing actively (metaplasia); ideally, there should not have any contact or any external stimuli, including the injus (influx) of foreign objects in a woman's body. The presence of a man's genitals and sperm cells will lead to abnormal cells' development, especially if it comes to injuries that lead to infection in the uterus. There is strong evidence that the incidence of cervical cancer has a strong correlation with many extrinsic factors, such as what is important is seldom found in virgin (virgin), the incidence is higher in those who marry dar I the unmarried, especially for the girl whom coitus first experienced at a very young age $<17$ years is known to stimulate the growth of cancer cells in women's gynecologic, because in the age range 12-17 years, changes in the cells are dividing actively (metaplasia), ideally no contact or any external stimuli, including injury (influx) of foreign objects in the female body. The presence of a foreign body, including the genitals of men and sperm cells, will lead to abnormal cells' development in the direction. Especially if it comes to injuries that can lead to infection in the uterus.

\section{CONCLUSION}

The researchers concluded that significant patients with a history of cervical cancer by the age of marriage and age at first sex. It is reinforced with previous theories. Further researchers are suggested to find other factors that may affect the incidence of cervical cancer.

Acknowledgements: This study (in part) was supported by the Faculty of Health Sciences, Kediri University, and Aisyiyah University, Yogyakarta, Indonesia.

\section{REFERENCES}

1. S. E. Waggoner, "Cervical cancer," Lancet, vol. 361, no. 9376, pp. 2217-2225, Jun. 2003, doi: 10.1016/S01406736(03)13778-6.

2. P. E. Castle, "Beyond Human Papillomavirus: The Cervix, Exogenous Secondary Factors, and the Development of Cervical Precancer and Cancer," J. Low. Genit. Tract Dis., vol. 8, no. 3, pp. 224-230, Jul. 2004, doi: 10.1097/00128360-200407000-00011.

3. G. F. Sawaya, "A 21-Year-Old Woman With Atypical Squamous Cells of Undetermined Significance," JAMA, vol. 294, no. 17, p. 2210, Nov. 2005, doi: 10.1001/jama.294.17.2210.

4. K. Milde-Langosch, S. Riethdorf, and T. Löning, "Association of human papillomavirus infection with carcinoma of the cervix uteri and its precursor lesions: theoretical and practical implications," Virchows Arch., vol. 437, no. 3, pp. 227-233, Sep. 2000, doi: 10.1007/s004280000234. 